\title{
COMMENTARY
}

\section{Experiments in social responsibility}

\section{Pursuing drugs for neglected diseases is not a traditional part of the pharmaceutical company portfolio. But Paul Herrling of Novartis finds that it brings welcome changes both within and outside the industry.}

D harmaceutical companies are commercial enterprises, and until recently were almost exclusively focused on generating maximal returns for their shareholders. We are now seeing more of these companies invest their hard-won returns in providing greater access to medicines for patients in poorer parts of the world. These projects have a distinctly charitable aspect to them and will not generate profits (see table overleaf for examples). The most recent initiative by the Swiss company Novartis, for which I work, is the creation of an institute in Singapore (the Novartis Institute for Tropical Diseases; NITD) dedicated to the discovery of drugs for tuberculosis and dengue. I believe that these activities are generating positive changes within our industry, and also in our relationships with our partners in these initiatives - non-governmental organizations (NGOs) and other stakeholders who are usually among our harshest critics.

In the past, most NGOs active in health care in the developing world considered the pharmaceutical business as part of the problem rather than a potential partner in any solutions. From my personal perspective, relations have greatly improved since Novartis established its 'access-to-medicines' projects. For example, the Global Alliance for Tuberculosis Drug Development (GATB) has sought our expertise in industrial drug discovery and has nominated me to
${ }^{u}$ In the past, most NGOs active in health care in the developing world considered the pharmaceutical business as part of the problem rather than a potential partner in any solutions."

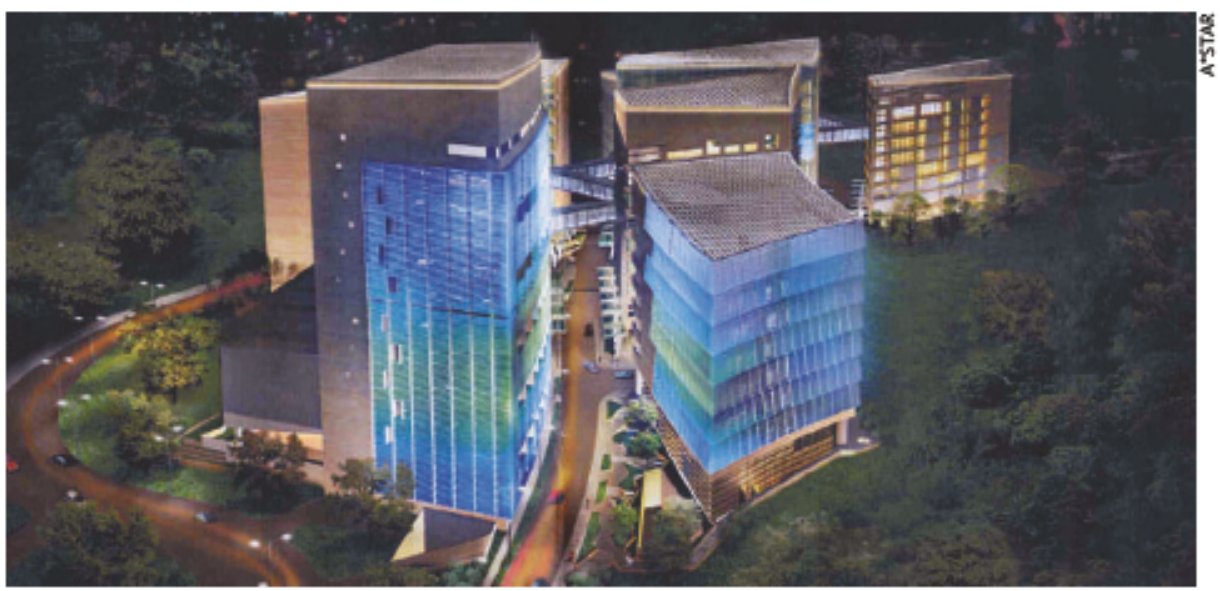

The new Novar tis Institute for Tropical Diseases in Singapore holds bright hopes for drug dis covery.

we are grateful for their willingness to teach us what they know about dengue and tuberculosis patients in Asia and Africa (see below).

Although many public-health NGOs remain highly critical of intellectual-property protection, both the DNDi and GATB engage, to different degrees, in 'defensive' patenting to protect medicines they helped to discover and develop. Defensive patenting means pursuing legal protections that allow them to do what they like with new drug compounds, including the right to make them available at cost without having to pay licences or royalties to any third their board. Yves Champey of the Drugs for Neglected Diseases initiative (DNDi), an offshoot of the medical aid agency Doctors Without Borders (or MSF), has also invited me to join their scientific advisory committee.

\section{On the defensive}

MSF used to be uniformly critical of the pharmaceutical industry, but now has a more heterogeneous attitude. Some individuals remain negative, as demonstrated by MSF's public criticism of Novartis when we ran into supply problems last year with the raw material for our malaria medicine Coartem, which we provide at cost to patients in Africa. Still, others within MSF have become partners and regular visitors to our Singapore institute, and parties, such as universities or biotech and pharmaceutical companies. Defensive patenting would even allow them to generate a return on investment should those medicines find customers in wealthy markets - a return they could use to finance further research and development into neglected diseases.

As well as the changing attitudes of NGOs, changes have also occurred within our industry. Projects on neglected diseases at Novartis have required adjustments in the way that drug-discovery scientists and other personnel operate. For example, to develop medicines it is imperative to understand precisely the patients' problems, their environment and the doctors treating them, as well as having the necessary access to patients or their tissues.
These are issues we understand well for the diseases of richer societies but less so for tropical diseases. In particular, we had little prior experience with patients affected by tuberculosis and dengue, which affect hundreds of millions of people worldwide each year.

\section{Lessons to be learnt}

Our first decision, and not a completely trivial one, was where to locate our new institute. Our existing research centres in Europe and the United States fulfilled all criteria for excellence except one proximity to patients and their doctors. This need drove a wider search that led us eventually to southeast Asia and Singapore. When we began our research activities at the NITD we were able to visit hospitals in neighbouring Cambodia, Vietnam, Indonesia and India to familiarize ourselves with conditions there. In addition, we visited tuberculosis and dengue patients in sub-Saharan Africa, where conditions differ from those in southeast Asia.

Our first lesson was the need for good, cheap and easy-to-use diagnostic methods, which are lacking for both diseases. Second, we learnt that treatments must not only be cheap to make, but simple to use in the field or in the relatively primitive conditions of district hospitals in these parts of the world. Any treatment requiring sophisticated equipment would not be viable, ruling out many 'high-tech' medical tools used by richer societies.

Third, we learnt that many prospective patients in these regions have a different understanding of medicine from us, and are 
not familiar with our 'scientific' approach to it. Most patients, particularly in rural regions, typically go to traditional healers first and have a mistrust of Western medicine. They will often only go to hospitals or health centres when traditional methods have failed. Sometimes this means their condition has deteriorated to a point that might have been avoided had they sought medical help earlier.

Patients in tropical regions are much more embedded in their local community than are Western patients, and consequently are best reached not as individuals but through the community. So, when introducing new therapies, it is important to gain the support of community leaders first and to communicate our medical concepts in ways that make sense within that culture. Experience shows that once this is achieved, patients in Africa, for instance, are actually more compliant in following a treatment regimen than are Western patients, who may second-guess their doctors and stop taking recommended medicines.

\section{Wider considerations}

Importantly, we learnt the significance of reinforcing infrastructure at locations where we wanted to conduct research or clinical studies, long before the new medicines are available. We also learnt to evaluate any potential corruption issues affecting an investment site,

\begin{tabular}{|c|c|c|c|c|}
\hline \multicolumn{5}{|c|}{ Work on neglected diseases by pharmaceutical companies and their par tners (see www.ippph.org) } \\
\hline Company & Project & When & Where & Partners \\
\hline GlaxoSmithKline & $\begin{array}{l}\text { RQD on oral malaria } \\
\text { treatments }\end{array}$ & 2000 and ongoing & Sub-Saharan Africa & $\begin{array}{l}\text { World Healt th Organization } \\
(W H O)\end{array}$ \\
\hline GlaxoSmithKline & $\begin{array}{l}\text { Albendazole donations } \\
\text { to combat elephantitis }\end{array}$ & 1998 and ongoing & 12 countries in Africa & $\begin{array}{l}\text { WHO, Bill \& Melinda Gates } \\
\text { Foundation, Merck, } \\
\text { national health minis tries }\end{array}$ \\
\hline GlaxoSmithKline & $\begin{array}{l}\text { Allocation of laboratory } \\
\text { resources for neglected } \\
\text { diseases }\end{array}$ & 2003 and ongoing & Madrid, Spain & $\begin{array}{l}\text { MMV for malaria, GATB } \\
\text { for tuberculosis }\end{array}$ \\
\hline Merck & $\begin{array}{l}\text { Donation of wermectin } \\
\text { to combat river } \\
\text { blindness }\end{array}$ & 1987 and ongoing & $\begin{array}{l}\text { Countries in Africa, } \\
\text { the Middle East and } \\
\text { Lat in America }\end{array}$ & $\begin{array}{l}\text { See wwwmectizan.org/ } \\
\text { partners.asp }\end{array}$ \\
\hline Merck & HN/AIDS partnership & 2004 & Botswana & $\begin{array}{l}\text { Bill \& Mel inda Gates } \\
\text { Foundation, government } \\
\text { of Botswana }\end{array}$ \\
\hline Novartis & $\begin{array}{l}\text { Donations of drugs for } \\
\text { leprosy }\end{array}$ & 2000 to 2010 & $\begin{array}{l}\text { All countries affected } \\
\text { by leprosy }\end{array}$ & $\begin{array}{l}\text { National health ministries, } \\
\text { WHO and NGOs }\end{array}$ \\
\hline Novartis & $\begin{array}{l}\text { Directly observed } \\
\text { therapy for tubercul osis }\end{array}$ & 2003 to 2007 & Tanzania & WHO \\
\hline Novartis & $\begin{array}{l}\text { Coartem made } \\
\text { availableat, or below, } \\
\text { cost to malaria patients }\end{array}$ & 2001 and ongoing & $\begin{array}{l}\text { All malaria-endemic } \\
\text { countries }\end{array}$ & $\begin{array}{l}\text { Chinese for drug } \\
\text { development WHO and } \\
\text { Global Fund for delivery }\end{array}$ \\
\hline Pfizer & $\begin{array}{l}\text { Donations of Diflucan } \\
\text { for infections in AIDS } \\
\text { patients }\end{array}$ & 2000 and ongoing & $\begin{array}{l}\text { Africa, Asia and the } \\
\text { Caribbean }\end{array}$ & $\begin{array}{l}\text { WHO, South African } \\
\text { government }\end{array}$ \\
\hline Sanofi-Aventis & Dengue vaccine project & 1993 and ongo ing & Thailand & $\begin{array}{l}\text { Mahidol University, } \\
\text { Bangkok and } \\
\text { Thai government }\end{array}$ \\
\hline Sanofi-Aventis & $\begin{array}{l}\text { Donations of drugs for } \\
\text { sleeping sickness }\end{array}$ & 2001 to 2006 & $\begin{array}{l}\text { Endemic countries in } \\
\text { Africa }\end{array}$ & $\begin{array}{l}\text { WHO, MSF, Bill \& Melinda } \\
\text { Gates Foundation }\end{array}$ \\
\hline
\end{tabular}

which are not only incompatible with our corporate ethics but also risk distorting scientific results, or placing researchers in danger. We were fortunate to find many hospitals and research centres that have dedicated and skilled local personnel who are capable of delivering impressive results in extremely difficult conditions. One example is the Ifakara Center in Tanzania, which has successfully conducted malaria clinical studies using good clinical practice standards. We are in the process of identifying similar sites in Africa and Asia and building relationships for research and clinical development. This is time-consuming and requires intensive investment in forming personal relationships.

For drug-discovery personnel, who are used to working for a large pharmaceutical company focused on patients in richer societies, this was a crucial learning experience for achieving their new goals on neglected tropical diseases. The final task was something we had to unlearn: to actively suppress our usual criteria for short-term commercial viability and accept that these projects will not have any financial returns.

Why have the attitudes of some pharmaceutical companies and their shareholders changed from exclusively seeking profits to a limited, but significant, support of access-tomedicine activities? Such investments would

$$
\text { tistis }
$$

.
som pacte some resources to diseases of poor societies so as to develop global defences against these potential threats.

A third factor, arising from within the industry, is the knowledge that pharmaceutical companies are currently seen by many outsiders in a negative light and that some companies would like to change this perception. This, in turn, improves morale within the company.

Of course, there are limits to what we can achieve. The prime mission of a commercial enterprise remains the generation of returns for investors, so only limited resources will be allocated to not-for-profit activities. And it is true that only commercially successful companies can afford such initiatives. But it is also the case that for some neglected diseases a fairly modest investment can have a huge impact.

Such not-for-profit activities would be impossible without personal commitment from the highest level of management. At Novartis, we are fortunate that our chairman, Daniel Vasella, is a medical doctor interested in accessto-medicine issues. He has encouraged us to think of contributions we could make in this area and consistently supported the solutions we proposed. These activities are new experiments for Novartis, and although we do not know how successful they will be, or how long they will be supported by our shareholders, we hope they will encourage others to do the same - to the benefit of all patients.

Paul Herrling is head of corporate research at Novartis International, $\mathrm{CH}-4002$ Basel, Switzerland. 